\title{
Kewenangan Dalam Mengawasi Lalu Lintas Barang Pada Free Trade Zone Menurut Hukum Internasional Dan Implikasi Free Trade Zone Terhadap Indonesia
}

\author{
Rahayu Repindowaty Harahap, Mochammad Farisi \\ Fakultas Hukum, Universitas Jambi, Indonesia
}

\begin{abstract}
ABSTRAK
Penelitian ini bertujuan untuk mengetahui apa saja kewenangan kepabeanan dalam mengawasi lalu lintas barang di Free Trade Zone (FTZ) ditinjau dari The Rivised Kyoto Convention 1999 dan untuk mengetahui bagaimana implikasi adanya Free Trade Zone terhadap pendapatan Negara Indonesia. Penelitian ini fokus pada pengaturan kewenangan kepabenan dalam mengawasi lalu lintas barang di Free Trade Zone ditinjau dari The Rivised Kyoto Convention 1999, dan untuk mengetahui bagaimana implikasi adanya Free Trade Zone tersebut terhadap pendapatan Negara Indonesia. Adapun target khusus yang ingin dicapai dari penelitian ini adalah untuk melihat pengaturan dan apa saja kewenangan kepabeanan dalam mengawasi lalu lintas barang pada Free Trade Zone serta melihat bagaimana implikasi dengan adanya FTZ tersebut bagi Indonesia, salah satunya adalah potensi pendapatan Negara. Mengingat bahwa FTZ adalah suatu konsep dalam perdagangan internasional maka aturan dasarnya dibentuk oleh institusi internasional juga yaitu institusi Kepabeanan dunia yang bernama World Customs Organization (WCO). Penelitian ini merupakan penelitian yuridis normatif (legal research) dengan pendekatan peraturan perundang-undangan (Statute Approach) akan ditelaah isi kaidah hukum dari The Rivised Kyoto Convention 1999 yaitu suatu konvensi internasional tentang penyederhanaan dan harmonisasi prosedur kepabeanan yang mengatur salah satunya terkait dengan pengawasan pada FTZ dimana kewenangan mengawasi segala hal yang berkaitan dengan aktivitas ekspor dan impor di Indonesia secara kelembagaan adalah Direktorat Jenderal Bea dan Cukai (Bea Cukai) sebagai institusi kepabeanan Indonesia.
\end{abstract}

Kata Kunci: Kewenangan, lalu lintas barang, free trade zone

\section{PENDAHULUAN}

Free Trade Zone (selanjutnya disingkat FTZ) merupakan suatu konsep dalam perdagangan internasional yang pengaturannya dilaksanakan oleh institusi kepabeanan dunia yang bernama World Customs Organization (WCO) dalam Chapter 2 Specific Annex D of The Revised Kyoto Convention (RKC) 1999. Chapter tersebut mengatur istilah FTZ ini disebut dengan Free Zone: "Free zones means a part of the territory of a Contracting Party where any goods introduced are generally regarded, insofar as import duties and taxes are concerned, as being outside the Customs territory", 1 (Kawasan Bebas berarti suatu bagian dari wilayah suatu Negara anggota dimana

\footnotetext{
${ }^{1}$ Chapter 2 Specific Annex D of the Revised Kyoto Convention 1999.
} 
setiap barang yang dibawa masuk ke dalamnya, sepanjang menyangkut bea masuk dan pajak, pada umumnya dianggap sebagai berada di luar daerah Pabean). Skema Free Zone ini di berbagai Negara disebut dengan banyak istilah selain Free Trade Zone, seperti: foreign-trade zones, duty free export processing zones, export free zones, export processing zones, free export zones, industrial free zones, investment promotion zones, maquiladoras (Mexico), free port, dan special economic zones. ${ }^{2}$

FTZ ini sejatinya adalah kawasan yang berada di wilayah Negara Kesatuan Republik Indonesia (NKRI), namun diberikan perkecualian (dispensasi) oleh Negara untuk tidak diberlakukannya Undang-undang (selanjutnya disingkat UU) Kepabeanan, UU Perpajakan khusus pajak dalam rangka impor, dan UU Cukai atas pemasukan dan pengeluaran barang ke dan dari kawasan tersebut. ${ }^{3}$ Dispensasi yang diberikan di kawasan FTZ sifatnya bersyarat, dimana hak Negara tersebut tidak dipungut sepanjang barang dimaksud dipakai habis atau digunakan hanya di dalam kawasan FTZ atau dikeluarkan ke luar daerah pabean setelah mengalami proses peningkatan mutu barang. Hak Negara akan dipungut atas barang dimaksud jika syarat tersebut tidak terpenuhi. Mengingat masih adanya potensi penerimaan Negara tersebut maka diperlukan pengawasan terhadap lalu lintas barang yang masuk dan keluar kawasan FTZ guna mengamankan hak-hak Negara.

Peraturan perundang-undangan yang mengatur skema FTZ ini juga mengalami perubahan-perubahan mengikuti perkembangan keadaan dalam Negeri dan perdagangan internasional dan terakhir pengaturan skema FTZ adalah dengan diundangkannya UU Nomor 44 Tahun 2007 tentang Penetapan PERPU Nomor 1 Tahun 2007 tentang Perubahan Atas UU Nomor 36 Tahun 2000 Tentang Penetapan Peraturan PERPU Nomor 1 Tahun 2000 tentang Kawasan Perdagangan Bebas Dan Pelabuhan Bebas Menjadi Undang-Undang. Berkaitan dengan itu, ada perubahan yang substansial pada UU FTZ yang terakhir ini, yaitu penetapan suatu wilayah menjadi kawasan FTZ dilaksanakan menggunakan Peraturan Pemerintah yang semulanya menggunakan UU. Wilayah di Indonesia yang merupakan kawasan FTZ hingga tahun 2018 sebagaimana hasil penelusuran peraturan perundang-undangan terdapat di 4 (empat) wilayah, yaitu: FTZ Sabang, FTZ Batam, FTZ Bintan, dan FTZ Karimun. ${ }^{4}$

Menurut sistem perdagangan internasional dan sistem pemerintahan Indonesia, diketahui bahwa yang memiliki kewenangan mengawasi segala hal yang berkaitan dengan aktivitas ekspor dan impor di Indonesia secara kelembagaan

\footnotetext{
${ }^{2}$ Gokhan Akinci dan James Crittle, Special economic zone : performance, lessons learned, and implication for zone development, Foreign Investment Advisory Service (FIAS) of The World Bank Group, Washington DC, 2008, hal. 9-11.

${ }^{3}$ Lihat Pasal 1 Ayat (1) Undang-Undang Nomor 36 Tahun 2000 Tentang Penetapan Peraturan Pemerintah Pengganti Undang-undang Nomor 1 Tahun 2000 Tentang Kawasan Perdagangan Bebas dan Pelabuhan Bebas Menjadi Undang-undang.

${ }^{4}$ Zona baru sebagaimana dimaksud ditentukan dalam berbagai peraturan perundang-undangan yang dibentuk dengan Undang-Undang dan Peraturan Pemerintah.
} 
adalah Direktorat Jenderal Bea dan Cukai (Bea Cukai) sebagai institusi kepabeanan Indonesia. Bea Cukai memiliki kewenangan ini secara atributif dengan diundangkannya UU Nomor 10 Tahun $1995^{5}$ tentang Kepabeanan sebagaimana telah diubah dengan UU Nomor 17 Tahun 2006. Menurut UU tersebut Bea Cukai memiliki kewenangan untuk membuat regulasi, menjalankan, dan melakukan penilaian atas pelaksanaan UU dimaksud. Hal-hal yang menjadi pengaturan adalah segala hal yang berhubungan dengan aktivitas ekspor dan impor barang, baik itu mengenai tata laksananya, pengawasannya, pemberian fasilitas kepabeanan dan pengawasan terhadap fasilitas yang diberikan, dan penegakan hukumnya. Sumber kewenangan Bea Cukai secara internasional untuk menerapkan sistem pengawasan kepabeanan terhadap lalu lintas barang yang masuk dan keluar kawasan FTZ. diatur dalam RKC 1999 pada bagian "Establishment and control" angka 3 yang menyatakan bahwa Bea Cukai harus menetapkan pengaturan tentang pengawasan kepabeanan termasuk persyaratan yang patut berkenaan dengan kesesuaian, konstruksi dan tata ruang kawasan bebas.

Tujuan umum penerapan skema FTZ adalah sebagai sarana untuk meningkatkan pertumbuhan ekonomi. Melalui FTZ promosi dapat dilakukan Pemerintah untuk menarik para investor baik dari luar negeri maupun dalam negeri. Pemerintah juga dapat mengembangkan dan mendiversifikasi ekspor sambil mempertahankan proteksi, menciptakan lapangan kerja, dan menjalankan kebijakan dan pendekatan baru (misalnya, dalam aspek kepabeanan, hukum, tenaga kerja, dan kemitraan pemerintah-swasta). Berdasarkan tujuan tersebut, sejatinya skema FTZ menghendaki lancarnya lalu lintas barang dalam perdagangan internasional, sama seperti FTA, melalui peniadaan hambatan dalam perdagangan (Trade Barrier). Hal tersebut akan memberi implikasi tersendiri bagi Indonesia, salah satunya terhadap pendapatan negara. Mengingat adanya potensi penerimaan Negara dikawasan FTZ nya, maka diperlukan pengawasan terhadap lalu lintas barang yang masuk dan keluar kawasan FTZ guna mengamankan hak-hak Negara. Bertolak dari hal-hal sebagaimana uraian di atas, penulis bermaksud melakukan penelitian yuridis normatif yang berjudul "Kewenangan Dalam Mengawasi Lalu Lintas Barang Pada Free Trade Zone Menurut Hukum Internasional Dan Implikasi Free Trade Zone Terhadap Indonesia".

\section{Rumusan Masalah}

Berdasarkan uraian di atas permasalahan yang akan diteliti adalah:

\footnotetext{
${ }^{5}$ Sebelum Undang-Undang Nomor 10 Tahun 1995 tentang Kepabeanan, kewenangan Bea Cukai dilaksanakan berdasarkan Indische Tarief Wet (Undang-undang Tarif Indonesia) Staatsblad Tahun 1873 Nomor 35, Rechten Ordonnantie (Ordonansi Bea) Staatsblad Tahun 1882 Nomor 240, dan Tarief Ordonnantie (Ordonansi Tarif) Staatsblad Tahun 1910 Nomor 628 yang masih diberlakukan berdasarkan Pasal II Aturan Peralihan UndangUndang Dasar 1945.
} 
1. Apa saja kewenangan kepabeanan dalam mengawasi lalu lintas barang pada Free Trade Zone ditinjau dari The Rivised Kyoto Convention (RKC) 1999?

2. Bagaimana implikasi adanya Free Trade Zone terhadap pendapatan Negara Indonesia?

\section{KAJIAN PUSTAKA}

\section{Definisi dan Tujuan Pengawasan}

Banyak pendapat para ahli yang tertuang dalam berbagai literatur terkait dengan definisi pengawasan ini, diantaranya yaitu Sondang Siagian bahwa pengawasan adalah proses pengamatan pelaksanaan seluruh kegiatan organisasi untuk menjamin agar semua pekerjaan yang dilaksanakan sesuai dengan rencana yang telah ditentukan sebelumnya. ${ }^{6}$ Terkait pengawasan yang dikaitkan dengan kegiatan kepabeanan yang utamanya adalah pengawasan terhadap lalu lintas barang yang masuk atau keluar batas Negara, maka pengawasan kepabeanan dapat diartikan sebagai segala upaya dan tindakan yang dilaksanakan oleh Bea Cukai agar pelaksanaan formalitas/kewajiban pabean berjalan sesuai dengan ketentuan peraturan perundang-undangan yang berlaku. ${ }^{7}$

Rencana organisasi kepabeanan (Bea Cukai) adalah segala hal yang tertuang dalam UU Nomor 10 Tahun 1995 tentang Kepabeanan sebagaimana telah diubah dengan UU Nomor 17 Tahun 2006 dan peraturan perundang-undangan di bawahnya, dan yang menjadi standar dalam pelaksanaan kegiatan adalah peraturan-peraturan Direktur Jenderal, surat edaran, instruksi, dan standard operating procedure (SOP) yang dikeluarkan oleh Bea Cukai. Dikaitkan dengan konteks kepabeanan, yang menjadi tujuan dari pengawasan kepabeanan adalah memastikan agar lalu lintas barang yang masuk atau keluar melewati batas Negara Indonesia menjalankan semua formalitas/kewajiban pabean, sebagaimana tertuang dalam UU Kepabeanan. Colin Vassarotti dalam Adrian Sutedi mengungkapkan bahwa tujuan pengawasan pabean adalah memastikan semua pergerakan barang, kapal, pesawat terbang, kendaraan, dan orang-orang yang melintas perbatasan Negara berjalan dalam kerangka hukum, peraturan, dan prosedur pabean yang ditetapkan. ${ }^{8}$

\section{Definisi Free Trade Zone}

Free Trade Zone (FTZ) merupakan fasilitas dalam rangka perdagangan internasional yang diterapkan oleh Negara anggota World Customs Organization (WCO) berdasarkan kesepakatan yang dituangkan dalam Chapter 2 Specific Annex D of The

\footnotetext{
${ }^{6}$ W. Riawan Tjandra, Hukum Keuangan Negara, Gramedia Widiasarana Indonesia, Jakarta, 2014, hal. 224.

${ }^{7}$ Dalam penjelasan lain, definisi pengawasan kepabeanan sebagaimana tersebut dalam Lampiran Umum The Revised Kyoto Convention (RKC) 1999 adalah tindakan yang dilakukan Pabean untuk memastikan kepatuhan terhadap Undang-Undang Kepabeanan.

${ }^{8}$ Adrian Sutedi, Aspek Hukum Kepabeanan, Sinar Grafika, Jakarta, 2012, hal. 61.
} 
Revised Kyoto Convention (RKC) 1999. Dalam Chapter tersebut istilah FTZ ini disebut dengan Free Zone:

Free zones means a part of the territory of a Contracting Party where any goods introduced are generally regarded, insofar as import duties and taxes are concerned, as being outside the Customs territory.

Terjemahan bebas dapat diartikan sebagai: 'Kawasan Bebas berarti suatu bagian dari wilayah suatu Negara anggota dimana setiap barang yang dibawa masuk ke dalamnya sepanjang menyangkut bea masuk dan pajak, pada umumnya dianggap sebagai berada di luar daerah pabean'. Chapter tersebut juga menyatakan dengan jelas bahwa kawasan FTZ merupakan suatu kawasan atau wilayah yang merupakan bagian dari suatu Negara serta sepanjang terkait dengan bea masuk dan pajak maka barang yang dibawa masuk ke kawasan FTZ dianggap sebagai berada di luar daerah pabean.

Jadi dapat dikatakan bahwa anggapan kawasan FTZ tersebut sebagai wilayah di luar daerah pabean adalah hanya sebatas ketidakberlakuan hukum fiskal Negara bersangkutan pada wilayah itu, sehingga hukum selain hukum fiskal masih berlaku sebagaimana wilayah lain dalam suatu Negara. Chapter tersebut juga menyatakan bahwa penetapan syarat yang berkaitan dengan pembentukan FTZ, jenis barang yang dapat dimasukkan ke kawasan tersebut dan kegiatan atau operasional yang diperbolehkan harus dicantumkan pada perundang-undangan

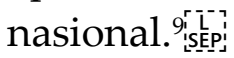

Sejalan dengan definisi yang diberikan oleh WCO di atas, Charles W. Thurston dalam Yusuf Effendy Harahap mengungkapkan definisi FTZ sebagai:

An Free Trade Zone is in essence, a tax-free enclave and not consideres part of the country as far as import regulations are concerned. When an item leaves an free trade zone and is officially imported into the host country of the Free Trade Zone, all duties and regulation are imposed..$^{10}$

Terjemahan bebas diartikan sebagai berikut: 'Suatu Kawasan Perdagangan Bebas pada intinya adalah suatu kawasan bebas pajak dan tidak dipertimbangkan sebagai bagian dari Negara sejauh menyangkut peraturan impor. Ketika suatu barang meninggalkan kawasan perdagangan bebas dan secara resmi diimpor (dimasukkan) ke Negara penyelenggara Kawasan Perdagangan Bebas tersebut, semua kewajiban dan peraturan diberlakukan'.

Gokhan Akinci dan James Crittle dalam kajiannya memberikan definisi mengenai FTZ sebagai berikut:

Free trade zones, also known as commercial free zones and free commercial zones, are small, fenced-in, duty-free areas, offering ware-housing, storage, and

\footnotetext{
${ }^{9}$ Lihat, Chapter 2 paragraph (2) Specific Annex D of The Revised Kyoto Convention (RKC) 1999.

${ }^{10}$ Yusuf Effendy Harahap, Kajian Teoritis Pengawasan Lalu Lintas Barang Pada Free Trade Zone (FTZ) Dalam Perspektif Peraturan Perundang-Undangan, Tesis, Fakultas Hukum Program Pasca Sarjana Ilmu Hukum. Universitas Jambi, Jambi, 2018, hal. 121-122.
} 
distribution facilities for trade, transshipment, and re-export operations, located in most ports of entry around the world. A leading example is the Colon Free Zone in Panama. ${ }^{11}$

Terjemahan bebas dapat diartikan dengan: 'Kawasan perdagangan bebas, juga dikenal sebagai commercial free zones dan free commercial zones, adalah area kecil, berpagar, bebas bea, menawarkan fasilitas gudang, penyimpanan, dan distribusi untuk perdagangan, kegiatan transshipment (pengiriman secara transit) dan reekspor, yang terletak dikebanyakan pelabuhan masuk diseluruh dunia. Contohnya adalah Colon Free Zone di Panama'.

\section{Tujuan dan Manfaat Free Trade Zone}

FTZ sejatinya adalah fasilitas dalam perdagangan internasional yang diterapkan di dalam wilayah kedaulatan Negara Kesatuan Republik Indonesia (daerah pabean) yang dianggap di luar daerah pabean. Faktor pengawasan lalu lintas barang yang masuk dan keluar kawasan FTZ menjadi hal yang sangat penting agar tujuan penerapan fasilitas skema FTZ ini dapat tercapai. Tujuan umum penerapan skema FTZ ini sendiri adalah sebagai sarana untuk meningkatkan pertumbuhan ekonomi dan melalui FTZ promosi dapat dilakukan Pemerintah untuk menarik para investor baik dari luar Negeri maupun dalam Negeri.

Pemerintah juga dapat mengembangkan dan mendiversifikasi ekspor sambil mempertahankan proteksi, menciptakan lapangan kerja, dan menjalankan kebijakan dan pendekatan baru (misalnya, dalam aspek kepabeanan, hukum, tenaga kerja, dan kemitraan pemerintah- swasta). Berdasarkan tujuan tersebut, sejatinya skema FTZ menghendaki lancarnya lalu lintas barang dalam perdagangan internasional, sama seperti FTA, melalui peniadaan hambatan dalam perdagangan (Trade Barrier) berupa hambatan tarif (tariff barrier) dan hambatan non tarif (non-tariff barrier). Selain pengamanan hak keuangan Negara, aspek-aspek seperti ideologi, politik, perekonomian, sosial budaya, dan keamanan Negara juga merupakan hal penting yang menjadi pertimbangan perlunya dilaksanakan pengawasan kepabeanan atas lalu lintas barang yang masuk dan keluar kawasan FTZ ini.

\section{METODE PENELITIAN}

Penelitian ini merupakan jenis penelitian yuridis normatif (legal research). Bertalian dengan penelitian normatif, penelitian ini mencakup penelitian terhadap asas-asas dan kaedah hukum mengenai bagaimana pengaturan kewenangan kepabeanan dalam mengawasi lalu lintas barang dalam FTZ yang dikaji ditinjau dari The Rivised

${ }^{11}$ Gokhan Akinci dan James Crittle, Op. Cit., hal. 10. 
Kyoto Convention 1999 serta implikasi adanya FTZ terhadap pendapatan Negara Indonesia, karena penelitian hukum adalah suatu proses untuk menemukan aturan hukum, prinsip-prinsip hukum, maupun doktrin-doktrin hukum guna menjawab isu hukum yang dihadapi. Hal ini sesuai dengan preskriptif ilmu hukum dimana penelitian hukum dilakukan untuk menghasilkan argumentasi, teori atau konsep baru sebagai preskripsi dalam menyelesaikan masalah yang dihadapi, karena jawaban yang diharapkan dari penelitian hukum adalah right, appropriate, inappropriate, atau wrong. ${ }^{12}$

Pendekatan yang digunakan adalah pendekatan peraturan perundangundangan (Statute Approach), dengan menelaah kerangka normatif instrumen hukum internasional dan instrumen hukum nasional tentang pengaturan kewenangan kepabeanan dalam mengawasi lalu lintas barang dalam FTZ serta implikasi adanya FTZ terhadap Negara Indonesia. Melalui pendekatan peraturan perundang-undangan (Statute Approach) akan ditelaah isi kaidah hukum dari The Rivised Kyoto Convention (RKC) 1999 yaitu suatu konvensi internasional tentang penyederhanaan dan harmonisasi prosedur kepabeanan yang mengatur salah satunya terkait dengan kewenangan pengawasan pada FTZ dimana kewenangan mengawasi segala hal yang berkaitan dengan aktivitas ekspor dan impor di Indonesia secara kelembagaan adalah Direktorat Jenderal Bea dan Cukai (Bea Cukai) sebagai institusi kepabeanan Indonesia.

\section{Pengumpulan Bahan Hukum}

Untuk mendapatkan bahan hukum yang diperlukan, digunakan beberapa metode alat pengumpul bahan hukum seperti untuk mendapatkan bahan hukum primer dilakukan melalui documentary research, sedangkan untuk mendapatkan bahan hukum sekunder dikumpulkan melalui studi pustaka (library research), yang kemudian dikaji dan dianalisis secara komprehensif. Penelitian kepustakaan terdiri atas:

\section{Bahan Hukum Primer}

Yaitu bahan hukum yang bersifat autoritatif artinya mempunyai otoritas, berupa peraturan perundang-undangan yang mengikat dalam penelitian ini, yang meliputi:

1) The Rivised Kyoto Convention 1999

2) Undang-Undang No. 36 Tahun 2000 Tentang Penetapan Peraturan Pemerintah Pengganti Undang-Undang Nomor 1 Tahun 2000 Tentang Kawasan Perdagangan Bebas Dan Pelabuhan Bebas Menjadi UndangUndang.

3) Undang-Undang Nomor 17 Tahun 2003 Tentang Keuangan Negara.

4) Undang-Undang Nomor 17 Tahun 2006 tentang Kepabeanan

12 Peter Mahmud Marzuki, 2006, Penelitian Hukum, Kencana, Jakarta, hal: 35. 
5) Undang-Undang Nomor 15 Tahun 2017 Tentang Anggaran Pendapatan Dan Belanja Negara Tahun Anggaran 2018.

\section{Bahan Hukum Sekunder}

Dimaknai sebagai bahan hukum yaitu berupa semua publikasi tentang hukum yang bukan merupakan dokumen-dokumen resmi, meliputi buku-buku teks, tesis, kamus-kamus hukum, jurnal-jurnal hukum.

\section{Tehnik Analisis Bahan Hukum}

Bahan hukum yang didapat akan dianalisa melalui pendekatan Undang-Undang (statute approach) dengan menggunakan metode content analisis (analisa isi) yaitu dengan menelaah semua Undang-Undang dan regulasi yang berhubungan dengan permasalahan dalam bentuk pasal-pasal, dimana pasal-pasal tersebut akan diinterpretasikan dengan teknik interpretasi gramatikal, sistematis (dogmatis), dan analogi.

\section{HASIL DAN PEMBAHASAN}

Kewenangan Kepabeanan dalam mengawasi lalu lintas barang pada Free Trade Zone Ditinjau Dari The Revised Kyoto Convention (RKC) 1999.

Sebagai anggota WCO sejak 30 April 1957, Indonesia memiliki kewajiban untuk melaksanakan The Revised Kyoto Convention (RKC) 1999 selaku pihak yang ikut menandatangani konvensi tersebut. Ditambah lagi dengan dikeluarkannya Peraturan Presiden Nomor 69 Tahun 2014 tentang Pengesahan International Convention on the Simplification and Harmonization of Customs Procedures, as amended yang isinya adalah The Revised Kyoto Convention (RKC) 1999 itu sendiri, menjadikan hukum internasional tersebut semakin tegas keberlakuannya dan menjadi hukum positif di Indonesia. Pengawasan kepabeanan yang dilaksanakan oleh Bea Cukai secara internasional diatur dalam Revised Kyoto Convention (RKC) 1999. Pada lampiran umumnya disebutkan tentang pengawasan kepabeanan sebagai berikut: "All goods, including means of transport, which enter or leave the Customs territory, regardless of whether they are liable to duties and taxes, shall be subject to Customs control". ${ }^{13}$ Norma ini secara bebas dapat diterjemahkan sebagai 'semua barang, termasuk sarana transportasi, yang memasuki atau meninggalkan daerah Pabean, tanpa memperhatikan terutang bea dan pajak atau tidak, wajib berada di bawah pengawasan kepabeanan'.

Berbicara tentang kewenangan Bea Cukai dalam mengawasi lalu lintas barang yang masuk dan keluar kawasan FTZ, pertanyaan yang muncul adalah dari mana kewenangan Bea Cukai itu berasal? Dalam mencari jawaban atas pertanyaan

\footnotetext{
${ }^{13}$ Chapter 6 Paragraph (6.1) General Annex of The Revised Kyoto Convention (RKC) 1999.
} 
ini dapat dikaji dari peraturan dasar yang mengatur tentang skema FTZ itu sendiri dan sebagaimana telah diketahui bahwa FTZ adalah suatu konsep dalam perdagangan internasional. Oleh karena itu, aturan dasarnya tentu dibentuk oleh institusi internasional juga yaitu WCO. Hal ini diatur dalam RKC 1999 pada bagian "Establishment and control" angka 3 disebutkan: "The Customs shall lay down the arrangements for Customs control including appropriate requirements as regards the suitability, construction and layout of free zones" yang berarti 'Bea Cukai harus menetapkan pengaturan tentang pengawasan kepabeanan termasuk persyaratan yang patut berkenaan dengan kesesuaian, konstruksi dan tata ruang kawasan bebas'. Inilah sumber kewenangan Bea Cukai secara internasional untuk menerapkan sistem pengawasan kepabeanan terhadap lalu lintas barang yang masuk dan keluar kawasan FTZ.

Adapun pengaturan pengawasan lalu lintas barang yang masuk dan keluar kawasan FTZ, lebih lanjut diatur dalam Chapter 2 Specific Annex $D$ of The Revised Kyoto Convention (RKC) 1999 yang khusus mengatur Free Zone. Pada chapter ini disebutkan:

1. The Customs shall lay down the arrangements for Customs controlincluding appropriate requirements as regards the suitability, construction and layout of free zones. ${ }^{14}$ Pengaturan tentang pengawasan kepabeanan termasuk persyaratan yang patut berkenaan dengan kesesuaian, konstruksi dan tata ruang kawasan bebas.

2. The Customs shall have the right to carry out checks at any time on the goods stored in a free zone. ${ }^{15}$ Bea Cukai berhak melakukan pemeriksaan setiap saat pada barang yang berada dalam kawasan bebas.

3. Admission to a free zone of goods brought from abroad should not be refused solely on the grounds that the goods are liable to prohibitions or restrictions other than those imposed on grounds of:

1) public morality or order, public security, public hygiene or health, or for veterinary or phytosanitary considerations; or

2) the protection of patents, trade marks and copyrights, irrespective of country of origin, country from which arrived or country of destination. in Goods which constitute a hazard, which are likely to affect other goods or which require special installations should be admitted only to free zones specially designed to receive them. ${ }^{16}$

Terhadap pemasukan barang ke FTZ atas barang yang langsung datang dari luar Negeri (luar daerah pabean) hanya boleh ditolak pemasukannya jika menyangkut 2 (dua) hal, yaitu:

1) kepentingan publik yang meliputi: moralitas atau ketertiban publik, scepikeamanan publik, kebersihan umum atau kesehatan, atau atas pertimbangan dokter hewan atau phytosanitary; atau

\footnotetext{
${ }^{14}$ Chapter 2 paragraph (3) Specific Annex D of The Revised Kyoto Convention (RKC) 1999.

${ }^{15}$ Chapter 2 paragraph (4) Specific Annex D of The Revised Kyoto Convention (RKC) 1999.

${ }^{16}$ Chapter 2 paragraph (6) Specific Annex D of The Revised Kyoto Convention (RKC) 1999.
} 
2) kepentingan dalam perlindungan hak paten, merek dagang dan hak cipta.

Jadi, atas pemasukan barang ke kawasan FTZ yang langsung datang dari luar negeri (luar daerah pabean) tidak boleh dihambat hanya dengan alasan barang tersebut terkena aturan larangan dan pembatasan (lartas) saja, tanpa ada alasan yang kuat seperti diatur pada norma di atas. ${ }^{17}$

4. No Goods declaration should be required by the Customs in respect of goods introduced into a free zone directly from abroad if the information is already available on the documents accompanying the goods. ${ }^{18}$ Tidak ada pemberitahuan Barang yang harus diminta oleh Bea Cukai sehubungan dengan barang yang dimasukkan ke kawasan bebas langsung dari luar Negeri jika informasi tersebut sudah tersedia pada dokumen yang menyertai barang.

5. National legislation shall enumerate the cases in which goods to be consumed inside the free zone may be admitted free of duties and taxes and shall lay down the requirements which must be met. ${ }^{19}$ Undang-undang nasional harus menyebutkan hal-hal dimana barang- barang yang akan dikonsumsi di dalam kawasan bebas dapat dimasukkan dengan pembebasan bea dan pajak serta harus menetapkan persyaratan yang harus dipenuhi.

6. Goods admitted to or produced in a free zone shall be permitted to be removed in part or in full to another free zone or placed under a Customs procedure, subject to compliance with the conditions and formalities applicable in each case..$^{20}$ Barang yang dimasukkan atau diproduksi di kawasan bebas harus diizinkan untuk dikeluarkan sebagian atau seluruhnya ke kawasan bebas lainnya di bawah prosedur kepabeanan, tunduk pada formalitas yang berlaku dalam setiap tahap.

7. The only declaration required for goods on removal from a free zone shall be the Goods declaration normally required for the Customs procedure to which those goods are assigned. ${ }^{21}$ Pemberitahuan yang diperlukan untuk barang-barang yang dikeluarkan dari kawasan bebas adalah pemberitahuan barang yang biasanya diperlukan dalam prosedur kepabeanan sesuai tujuan barang-barang tersebut dikeluarkan.

8. Where a document must be produced to the Customs in respect of goods which on

\footnotetext{
17 Aturan larangan dan pembatasan (Lartas) merupakan aturan mengenai jenis-jenis barang yang dilarang dan/atau dibatasi pemasukan maupun pengeluarannya ke dan dari Indonesia, yang dikeluarkan oleh instansi teknis terkait, yaitu kementerian dan lembaga pemerintah non- kementerian tingkat pusat. Tujuan utama lartas ini adalah untuk melindungi (proteksi) rakyat dan bangsa dari efek negatif yang mungkin ditimbulkan oleh praktik perdagangan internasional.

${ }^{18}$ Chapter 2 paragraph (9) Specific Annex D of The Revised Kyoto Convention (RKC) 1999.

${ }^{19}$ Chapter 2 paragraph (13) Specific Annex D of The Revised Kyoto Convention (RKC) 1999.

${ }^{20}$ Chapter 2 paragraph (16) Specific Annex D of The Revised Kyoto Convention (RKC) 1999.

${ }^{21}$ Chapter 2 paragraph (17) Specific Annex D of The Revised Kyoto Convention (RKC) 1999.
} 
removal from a free zone are sent directly abroad, the Customs should not require more information than already available on the documents accompanying the goods.22 Terkait dokumen yang harus dibuat untuk Bea Cukai sehubungan dengan barang yang dikeluarkan dari kawasan bebas dan dikirim langsung ke luar negeri, Bea Cukai seharusnya tidak memerlukan informasi lebih dari yang sudah tersedia pada dokumen yang menyertai barang.

Berdasarkan pengaturan pengawasan lalu lintas barang pada FTZ yang diatur secara internasional di atas, dapat disimpulkan bahwa Bea Cukai memiliki wewenang untuk menerapkan sistem pengawasan kepabeanan terhadap lalu lintas barang yang masuk dan keluar kawasan FTZ. Namun, sistem pengawasan yang diterapkan terhadap lalu lintas barang pada kawasan FTZ ini dilaksanakan dengan efektif dan efisien sehingga jangan sampai malah menghambat arus lalu lintas barang yang dapat mengakibatkan penerapan skema kawasan FTZ ini tidak sesuai dengan tujuan pembentukannya. Hal ini terlihat dengan adanya syarat dalam penerapan sistem pengawasan kepabeanan ini yang harus menggunakan manajemen risiko.

\section{Implikasi adanya Free Trade Zone Terhadap Pendapatan Negara Indonesia.}

Keberadaan kawasan FTZ sejatinya akan mendorong kegiatan-kegiatan perdagangan internasional, yang di samping memberi pengaruh besar dalam memajukan kegiatan ekonomi dalam negeri, juga dapat dijadikan sebagai sumber penting pendapatan devisa yang merupakan sumber pembiayaan penting dalam pembangunan ekonomi. Secara konkret tidak dapat disangkal bahwa ada korelasi kuat antara perdagangan intemasional dengan pertumbuhan ekonomi nasional, oleh karena itu upaya untuk meningkatkan kegiatan perdagangan internasional tersebut dimaksudkan juga untuk meningkatkan pertumbuhan ekonomi nasional. Salah satu upaya yang dipercaya dapat meningkatkan pertumbuhan ekonomi suatu negara secara cepat adalah melalui penerapan skema FTZ.

Penerapan skema FTZ ini jika dikaitkan dengan pendapatan negara, ada baiknya terlebih dahulu diketahui bahwa definisi pendapatan negara dalam peraturan perundang-undangan adalah hak pemerintah pusat yang diakui sebagai penambah nilai kekayaan bersih. ${ }^{23}$ Pendapatan negara merupakan gambaran mengenai jumlah uang ataupun barang yang diterima oleh negara sebagai bagian dari pelaksanaan hak negara, baik yang bersumber dari masyarakat maupun dari pihak lainnya yang digunakan sebagai instrumen pembiayaan terhadap pengeluaran yang dilakukan oleh negara. Selanjutnya, sebagaimana diatur dalam peraturan perundang-undangan bahwa pendapatan negara terdiri atas penerimaan

\footnotetext{
${ }^{22}$ Chapter 2 paragraph (18) Specific Annex D of The Revised Kyoto Convention (RKC) 1999.

${ }^{23}$ Lihat, Pasal 1 angka (13) Undang-Undang Nomor 17 Tahun 2003 tentang Keuangan Negara.
} 
pajak, penerimaan bukan pajak, dan hibah. ${ }^{24}$ Dikarenakan dalam penerapan skema FTZ negara memberikan insentif fiskal, maka kaitannya adalah dengan penerimaan negara dibidang perpajakan. Sementara itu, penerimaan negara dibidang perpajakan sendiri merupakan semua penerimaan negara yang bersumber dari sektor perpajakan dan terdiri atas pendapatan pajak dalam negeri dan pendapatan pajak perdagangan internasional. ${ }^{25}$

Terkait frasa "pendapatan pajak dalam negeri", dalam peraturan perundang-undangan diartikan sebagai semua penerimaan negara yang berasal dari pendapatan pajak penghasilan, pendapatan pajak pertambahan nilai barang dan jasa dan pajak penjualan atas barang mewah, pendapatan pajak bumi dan bangunan, pendapatan cukai, dan pendapatan pajak lainnya. ${ }^{26}$ Dari uraian tersebut diketahui bahwa, pajak penghasilan ( $\mathrm{PPh}$ ) dan cukai termasuk dalam kategori pajak dalam negeri. Mengenai frasa "pendapatan pajak perdagangan internasional", dalam peraturan perundang-undangan diartikan sebagai penerimaan negara yang berasal dari pendapatan bea masuk dan pendapatan bea keluar. ${ }^{27}$ Kemudian, di dalam Undang-Undang Kepabeanan, bea masuk didefinisikan sebagai pungutan negara berdasarkan Undang-Undang Kepabeanan yang dikenakan terhadap barang yang diimpor ${ }^{28}$ dan bea keluar sebagai pungutan negara berdasarkan Undang-Undang Kepabeanan yang dikenakan terhadap barang ekspor. ${ }^{29}$

Kaitannya dengan penerapan skema FTZ yang merupakan skema fasilitasi dalam perdagangan internasional, maka pendapatan negara yang mendapat pengaruh secara langsung adalah pendapatan negara dari sektor pajak baik itu pajak dalam negeri maupun pajak perdagangan internasional, yaitu: 1) Bea Masuk 2) Bea Keluar, 3) PPN, 4) PPnBM, dan 5) Cukai. Namun, di dalam membahas hal ini harus dicermati secara menyeluruh mengenai elemen-elemen perpajakan yang mana saja yang terpengaruh dengan penerapan skema FTZ dihubungkan dengan definisi FTZ yang tersebut di dalam Undang-Undang FTZ. Terhadap barang yang masuk dan keluar kawasan FTZ diberikan pembebasan bea masuk, pembebasan pajak pertambahan nilai, pembebasan pajak penjualan atas barang mewah, dan pembebasan cukai serta diberlakukan ketentuan tata laksana di bidang impor dan ekspor dan ketentuan cukai. Berdasarkan hal-hal tersebut, dapat dikatakan bahwa dengan diterapkannya skema FTZ ini, maka dari sisi pendapatan negara dibidang perdagangan internasional (ekspor dan impor) secara umum akan mengalami

\footnotetext{
${ }^{24}$ Lihat, Pasal 11 ayat (3) Undang-Undang Nomor 17 Tahun 2003 tentang Keuangan Negara.

${ }^{25}$ Lihat,Pasal 1 angka (3) Undang-Undang Nomor 15 Tahun 2017 tentang Anggaran Pendapatan Dan Belanja Negara Tahun Anggaran 2018.

${ }^{26}$ Lihat,Pasal 1 angka (4) Undang-Undang Nomor 15 Tahun 2017 tentang Anggaran Pendapatan Dan Belanja Negara Tahun Anggaran 2018.

${ }^{27}$ Lihat,Pasal 1 angka (5) Undang-Undang Nomor 15 Tahun 2017 tentang Anggaran Pendapatan Dan Belanja Negara Tahun Anggaran 2018.

${ }^{28}$ Lihat, Pasal 1 angka (15) Undang-Undang Nomor 17 Tahun 2006 tentang Kepabeanan.

${ }^{29}$ Lihat, Pasal 1 angka (15a) Undang-Undang Nomor 17 Tahun 2006 tentang Kepabeanan.
} 
pengurangan. Pengurangan ini dikarenakan hilangnya potensi pendapatan negara terhadap lalu lintas barang asal luar daerah pabean ke kawasan FTZ yang notabenenya dianggap sebagai wilayah di luar daerah pabean, yaitu bea masuk, bea keluar, PPN, PPnBM, dan cukai impor. Namun, kekurangan pendapatan negara sebagai akibat penerapan skema FTZ sesungguhnya tidaklah benar-benar hilang, hanya bertransformasi menjadi pendapatan dalam bentuk lain.

Pungutan negara yang seharusnya diterima dalam aktivitas lalu lintas barang asal luar daerah pabean ke dalam daerah pabean digantikan dengan adanya investasi yang masuk ke kawasan FTZ sebagai sumber pendapatan devisa negara. Dengan banyaknya investasi yang masuk ke kawasan, diharapkan akan terjadi penyerapan tenaga kerja yang akan meningkatkan ekonomi individu dan rumah tangga secara finansial. Ekonomi masyarakat disekitar kawasan juga akan meningkat dengan pendirian usaha-usaha yang dapat mendukung kegiatan industri di kawasan. Dengan adanya peningkatan secara ekonomi tersebut, maka otomatis daya beli masyarakat pun akan meningkat dan pastinya ini akan secara langsung meningkatkan pendapatan pajak dalam negeri di samping pendapatan devisa negara yang juga meningkat akibat transaksi-transaksi perdagangan internasional yang terjadi di kawasan FTZ. Inilah proses terjadinya transformasi penerimaan negara tersebut sebagai akibat dari penerapan skema FTZ.

Secara umum penerapan skema FTZ di Indonesia memang belum bisa mendongkrak peningkatan pertumbuhan ekonomi nasional secara signifikan. Peningkatan pertumbuhan ekonomi nasional sampai saat ini masih bisa dikatakan merangkak, begitu juga jika dilihat secara lokal. Secara lokal dampak yang dirasakan atas penerapan skema FTZ ini hanya sebatas peningkatan pola konsumsi penduduk di kawasan dan peningkatan penyerapan tenaga kerja yang mengurangi pengangguran. Sementara manfaat lain seperti transfer teknologi, pertumbuhan dan diversifikasi ekspor, devisa, investasi asing langsung (FDI), peningkatan keterampilan dan pendapatan negara masih belum terlihat dengan kentara. Peningkatan pertumbuhan ekonomi yang melambat ini besar kaitannya dengan peraturan perundang-undangan yang dikeluarkan pemerintah terkait regulasi pengelolaan kawasan FTZ dan mekanisme lalu lintas barang pada kawasan FTZ. Regulasi yang tidak konsisten, multi tafsir, dan ruwet menyebabkan para investor masih enggan untuk beramai-ramai menanamkan modalnya di kawasan FTZ. Selain itu pengusaha yang sudah sempat berinvestasi di kawasan FTZ, malah sudah ada yang hengkang dari kawasan untuk berinvestasi di negara lain. Sebut saja salah satunya PT. Nidec Component Technology Indonesia yang merumahkan 661 tenaga kerja lokal dan 7 tenaga kerja asing setelah hengkang dari FTZ Batam. ${ }^{30}$

\footnotetext{
${ }^{30}$ Lihat, Muhammad Zuhri, "5 Perusahaan Asing di Batam Tutup Total, Baru Setahun Buka, Ribuan Karyawan Di-PHK”, http://batamnews.co.id/berita-24761-5-perusahaan-asing-di- batam-tutup-total-baru-setahun-bukaribuan-karyawan-diphk.html, 2017, diakses tanggal 27 Mei 2020 jam 19.00 wib.
} 


\section{KESIMPULAN DAN SARAN}

\section{Kesimpulan}

1. Pengawasan kepabeanan yang dilaksanakan oleh Bea Cukai secara internasional diatur dalam Lampiran Umum the Revised Kyoto Convention (RKC) 1999 dan Chapter 2 Specific Annex D of The Revised Kyoto Convention (RKC) 1999. Sumber kewenangan Bea Cukai secara internasional untuk menerapkan sistem pengawasan kepabeanan terhadap lalu lintas barang yang masuk dan keluar kawasan FTZ diatur dalam RKC 1999 pada bagian "Establishment and control" angka 3 disebutkan: "The Customs shall lay down the arrangements for Customs control including appropriate requirements as regards the suitability, construction and layout of free zones" yang berarti 'Bea Cukai harus menetapkan pengaturan tentang pengawasan kepabeanan termasuk persyaratan yang patut berkenaan dengan kesesuaian, konstruksi dan tata ruang kawasan bebas. Ada 8 (delapan) pengaturan pengawasan lalu lintas barang yang masuk dan keluar kawasan FTZ yang diatur dalam Chapter 2 Specific Annex D of The Revised Kyoto Convention (RKC) 1999 yang khusus mengatur Free Zone.

2. Penerapan skema FTZ ini maka dari sisi pendapatan negara dibidang perdagangan internasional (ekspor dan impor) secara umum akan mengalami pengurangan. Pengurangan ini dikarenakan hilangnya potensi pendapatan negara terhadap lalu lintas barang asal luar daerah pabean ke kawasan FTZ yang notabenenya dianggap sebagai wilayah di luar daerah pabean, yaitu bea masuk, bea keluar, PPN, PPnBM, dan cukai impor. Penerapan skema FTZ di Indonesia memang belum bisa mendongkrak peningkatan pertumbuhan ekonomi nasional secara signifikan.

\section{Saran}

1. Berdasarkan konsep FTZ pada UU maka sejatinya skema FTZ menghendaki kelancaran arus lalu lintas barang yang masuk dan keluar kawasan tersebut. Kelancaran ini diperoleh melalui pengaturan mengenai mekanisme lalu lintas barang dan mekanisme pengawasan atas lalu lintas barang tersebut. Berdasarkan uraian-uraian terdahulu telah diketahui bahwa secara prinsip pengawasan yang dilaksanakan oleh Bea Cukai sifatnya adalah menghambat arus lalu lintas barang. Oleh karena itu, relaksasi pengaturan kepabeanan sangat diperlukan dan yang terpenting juga adalah kesamaan persepsi mengenai konsep lalu lintas barang pada kawasan FTZ antara UU dengan peraturan Pemerintah di bawahnya. Kesamaan persepsi mengenai konsep lalu lintas barang pada kawasan FTZ dimaksud, yaitu: 1). Lalu lintas barang dari kawasan FTZ ke dalam daerah pabean adalah is șepiaktivitas impor, 2). Lalu lintas barang dari dalam daerah pabean ke kawasan FTZ adalah is íp.jaktivitas ekspor, dan 3). 
Lalu lintas barang yang terjadi antar kawasan FTZ serta antara isepikawasan FTZ dengan luar daerah pabean bukan kegiatan impor dan išepiekspor.

2. Keberhasilan penerapan skema FTZ untuk mempercepat pertumbuhan ekonomi sangat bergantung kepada political will Pemerintah di dalam penerapan skema ini selaku pemegang kekuasaan pemerintahan. Seiring dengan berjalannya reformasi birokrasi yang ada saat ini sudah seharusnya tujuan untuk menyejahterakan rakyat melalui percepatan pertumbuhan ekonomi terutama pada daerah yang di wilayahnya terdapat kawasan FTZ menjadi fokus perhatian Pemerintah. Upaya awal yang dapat dilakukan oleh Pemerintah adalah dengan pembentukan peraturan perundang-undangan FTZ yang baik dengan berlandaskan kepada prinsip kehati-hatian dan asas keseimbangan dalam pembentukan peraturan perundang-undangan.

\section{DAFTAR PUSTAKA}

\section{Buku}

Adrian Sutedi. 2012. Aspek Hukum Kepabeanan. Sinar Grafika. Jakarta.

Ali Purwito M. 2013. Kepabeanan Indonesia: Konsep, Kebijakan dan Penerapan.

Jelajah Nusa. Tangerang.

Bambang Semedi. 2010. Penegakan Hukum Kepabeanan Dan Cukai I. Bahan Ajar. Sekolah Tinggi Akuntansi Negara. Jakarta.

Dedi Abdul Hadi. 2017. Pengantar Free Trade Agreement. Badan Pendidikan dan Pelatihan Pusdiklat Bea dan Cukai. Jakarta.

------. 2017. Rules of Origin. Badan Pendidikan dan Pelatihan Pusdiklat Bea dan Cukai. Jakarta.

Gokhan Akinci dan James Crittle. 2008. Special economic zone : performance, lessons learned, and implication for zone development. Foreign Investment Advisory Service (FIAS) of The World Bank Group. Washington DC.

Peter Mahmud Marzuki, 2006, Penelitian Hukum, Kencana Prenada Media, Jakarta.

Ridwan HR. 2014. Hukum Administrasi Negara. Edisi Revisi. Rajawali Pers. Jakarta.

Serian Wijatno dan Ariawan Gunadi. 2014. Perdagangan Bebas Dalam Perspektif Hukum Perdagangan Internasional. Grasindo. Jakarta.

W. Riawan Tjandra. 2014. Hukum Keuangan Negara. Gramedia Widiasarana Indonesia. Jakarta

\section{Tesis dan Jurnal}

Yusuf Effendy Harahap. 2018. Kajian Teoritis Pengawasan Lalu Lintas Barang Pada Free Trade Zone (FTZ) Dalam Perspektif Peraturan Perundang-Undangan. Tesis. Jambi. Fakultas Hukum Program Pasca Sarjana Ilmu Hukum. Universitas Jambi. 
Rahayu Repindowaty Harahap dan Budi Ardianto. 2019. Pengaturan Pengawasan Lalu Lintas Barang Pada Free Trade Zone Ditinjau Dari The Rivised Kyoto Convention 1999 , Jurnal Sains Sosio Humaniora Volume 3 Nomor 2 Desember 2019, Universitas Jambi.

\section{Peraturan Perundang-undangan}

Undang-Undang Republik Indonesia Tentang Kepabeanan. UU Nomor 10 Tahun 1995.

Undang-Undang Republik Indonesia Tentang Penetapan Peraturan Pemerintah Pengganti Undang-Undang Nomor 1 Tahun 2000 Tentang Kawasan Perdagangan Bebas Dan Pelabuhan Bebas Menjadi Undang-Undang. UU Nomor 36 Tahun 2000.

Undang-Undang Republik Indonesia Tentang Keuangan Negara. UU Nomor 17 Tahun 2003.

Undang-Undang Republik Indonesia Tentang Perubahan atas Undang-Undang Nomor 10 Tahun 1995 tentang Kepabeanan. UU Nomor 17 Tahun 2006.

Undang-Undang Republik Indonesia Tentang Perubahan atas Undang-Undang Nomor 11 Tahun 1995 tentang Cukai. UU Nomor 39 Tahun 2007.

Undang-Undang Republik Indonesia Tentang Anggaran Pendapatan Dan Belanja Negara Tahun Anggaran 2018. UU Nomor 15 Tahun 2017.

Peraturan Pemerintah Pengganti Undang-Undang Tentang Perubahan Atas Undang-Undang Nomor 36 Tahun 2000 Tentang Penetapan Peraturan Pemerintah Pengganti Undang-Undang Nomor 1 Tahun 2000 Tentang Kawasan Perdagangan Bebas Dan Pelabuhan Bebas Menjadi Undang-Undang. Perppu Nomor 1 Tahun 2007.

Peraturan Pemerintah Tentang Perlakuan Kepabeanan, Perpajakan, Dan Cukai Serta Tata Laksana Pemasukan Dan Pengeluaran Barang Ke Dan Dari Serta Berada Di Kawasan Yang Telah Ditetapkan Sebagai Kawasan Perdagangan Bebas Dan Pelabuhan Bebas. PP Nomor 10 Tahun 2012.

\section{Konvensi Internasional}

The Revised Kyoto Convention (RKC) 1999

\section{Internet}

Muhammad Zuhri, "5 Perusahaan Asing di Batam Tutup Total, Baru Setahun Buka, Ribuan Karyawan Di-PHK", http://batamnews.co.id/berita-24761-5perusahaan-asing-di- batam-tutup-total-baru-setahun-buka-ribuan-karyawandiphk.html, 2017, diakses tanggal 27 Mei 2020 jam 19.00 wib. 